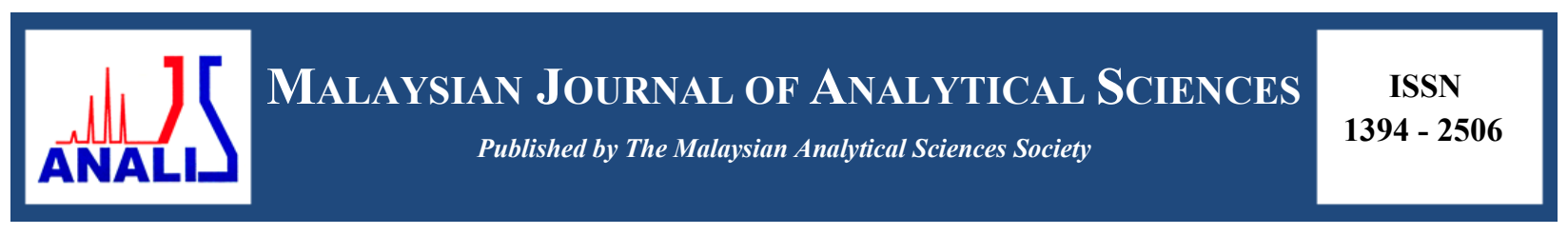

\title{
APPLICATION OF PROTEOLYTIC ENZYME IN HIGH AMMONIATED NATURAL RUBBER LATEX
}

\section{(Aplikasi Enzim Proteolitik dalam Lateks Getah Asli Berammonia Tinggi)}

\author{
Aziana Abu Hassan ${ }^{1 *}$, Norazreen Abd Rahman ${ }^{2}$, Nurulhuda Abdullah ${ }^{1}$, Roslinda Sajari ${ }^{3}$, Mok Kok Lang ${ }^{1}$ \\ ${ }^{1}$ Technology and Engineering Division \\ ${ }^{2}$ Production Development Division \\ ${ }^{3}$ Genomics and Bioinformatics Centre \\ Malaysian Rubber Board, 47000 Sg. Buloh, Selangor, Malaysia \\ *Corresponding author: aziana@lgm.gov.my
}

Received: 4 December 2016; Accepted: 1 December 2017

\begin{abstract}
Natural rubber latex (NRL) with 'low protein content' is regarded as alternative raw material for less allergenic latex. However, these 'low protein latexes' have been reported to give uncertain and at times poorer mechanical properties in which could be due to its method of preparation. Therefore this study was conducted to strengthen the fundamental approach of making 'low protein latex' via enzymatic treatment. Proteolytic enzymes were employed to digest the proteins and inactivate some of the proteins function. The aim was to study the effect of enzymatic treatment towards the nitrogen content in NRL that is mainly contributed by the presence of proteins. Impact on the mechanical properties due to changes in the native proteins was also evaluated. Results show that proteolytic enzyme at low concentration effectively hydrolysed the protein molecules. However, nitrogen content in NRL serum was simultaneously increased with increasing enzyme concentration. This could be due to the tendency of enzyme to form new peptides bonds known also as aminolysis. Interestingly, the amount of allergenic proteins was observed to decrease proportionally with the upsurge of enzyme concentration, suggesting deactivation of allergenicity by the enzyme. These preliminary results indicate a potential approach to produce low allergenic risk NRL products.
\end{abstract}

Keywords: low protein latex, proteolytic enzyme, protein allergy, mechanical properties

\section{Abstrak}

Lateks getah asli (LGA) dengan 'kandungan protein rendah' dianggap sebagai bahan mentah alternatif untuk mengurangkan risiko alahan terhadap protein LGA. Walau bagaimanapun, 'lateks protein rendah' menyebabkan sifat mekanikal lateks tersebut terjejas dan bergantung juga kepada kaedah penyediaannya. Oleh itu kajian ini dijalankan untuk mengukuhkan pendekatan asas dalam membuat 'lateks protein rendah' melalui rawatan enzimatik. Enzim proteolitik digunakan untuk mencerna protein dan menyahaktifkan beberapa fungsi protein. Tujuannya adalah untuk mengkaji kesan rawatan enzimatik ke atas kandungan nitrogen dalam LGA yang secara tidak langsung dapat mengesan kehadiran protein. Perubahan secara mekanikal akibat perubahan protein juga dinilai. Keputusan menunjukkan bahawa enzim proteolitik pada kepekatan rendah berupaya menghidrolisis molekul protein. Walau bagaimanapun, kandungan nitrogen dalam serum LGA meningkat dengan peningkatan kepekatan enzim. Ini mungkin disebabkan oleh kecenderungan enzim untuk membentuk jaringan peptida baru yang dikenali juga sebagai aminolisis. Menariknya, jumlah protein penyebab alahan berkurangan secara berkadar dengan peningkatan kepekatan enzim. Ini menunjukkan rawatan enzim berkemungkinan berupaya untuk menyahaktifan aktiviti protein penyebab alahan tersebut. Keputusan awal ini menunjukkan pendekatan berpotensi untuk menghasilkan produk LGA dengan risiko alahan yang rendah.

Kata kunci: lateks protein rendah, enzim proteolitik, alahan protein, sifat mekanikal 


\section{Introduction}

Natural rubber latex (NRL) is a stable dispersion of cis-1,4-polyisoprene rubber encapsulated in mostly spherical particles with average size of $0.15 \mu \mathrm{m}$ to $3 \mu \mathrm{m}$, in an aqueous phase [1]. The dispersed phase of NRL is mainly rubber hydrocarbon and the dispersion medium is water. Freshly-tapped NRL as obtained from the tree is a whitish fluid of density $0.975-0.980 \mathrm{~g} / \mathrm{ml}$ and with a $\mathrm{pH}$ from $6.0-7.0$ [2]. Being a natural product, its composition varies between a wide range. Typically NRL consists of $36 \%$ of total solid content including dry rubber content of $33 \%$, proteinaceous substances about $1 \%$, resinous substances $1-2.5 \%$, ash and sugar $1 \%$ respectively, and $60 \%$ content of water [3].

These substances are distributed between three principal phases namely, rubber particles ( $35 \%$ of latex by weight), the aqueous phase $(55 \%)$ and the remaining lutoid phase (10\%) [4]. The aqueous non-rubber phase is made up of carbohydrates (quebrachitol, sucrose, glucose, fructose and raffinose), proteins and amino acids ( $\alpha$-globulin and hevein) and other serum constituents (free nitrogenous bases, lipids, organic acids, inorganic anions and metallic ions) and a range of enzymes [5]. According to Tata, fresh NRL contains $0.95 \%$ proteins of which $27.2 \%$ is in the rubber fraction, $47.5 \%$ in the serum fraction and $25.3 \%$ on the bottom fraction. Technically, about $60 \%$ of the protein content is dissolved in the aqueous phase, approximately $20 \%$ is adsorbed on the surface of rubber particles and the remaining $20 \%$ is associated with the larger particulate bodies such as lutoids and Frey-Wyssling particles [6].

NRL proteins are commonly related to allergenic issues associated with the usage of latex-based products. In 1986, researches had revealed that the allergic reactions to latex products were instead IgE-mediated and that the allergens were latex proteins which still remained in the finished products $[7,8]$. Since then, most of research studies were conducted as precaution measures to minimize the latex proteins allergenic risk. Currently, low protein latexes are widely available in the market with various methods employed to deplete the proteins. Generally, low protein latex can be prepared via few approaches namely mechanical, chemical or biological treatment $[9,10,11]$. The mechanical process usually involves multiple centrifugation or membrane filtration of diluted latex. In chemical treatment, chemicals such as urea are used to remove proteins while biological approach usually involves combination of proteolytic enzymes.

Non-rubber components especially proteins are important in maintaining latex colloidal stability. Due to their solubility behaviour, proteins are found abundantly in the serum fraction upon centrifugation while the rest are surface-bound to rubber particles. Additionally, the process of concentrating the latex to about $60 \%$ rubber content also significantly reduces the protein content. In the technological aspect, proteins are regarded as an essential component that any alteration towards its composition can implicate on the products' properties [12,13]. A study by Gazeley had shown that overall rate of crosslink insertion during prevulcanization reaction is reduced for low protein NRL [14]. This finding was also supported by Yatim [15] that claimed the presence of non-rubbers accelerates prevulcanization rate during latex stage. However until now, it is unclear which non-rubber substituents are important in determining the rate at which the reaction occurs. The rate of prevulcanization could be a consequence of synergism between the non-rubber substances in NRL [12].

In this study, high ammoniated NRL (HA-NRL) was treated with a proteolytic enzyme known as alcalase in order to determine its digestive effects on the native proteins. To investigate this, HA-NRL was mixed with alcalase in various concentrations from $1 \%$ to $4 \%$ and incubated for two hours. Changes on the native proteins in HA-NRL were determined by measurement of total protein content (N\%) and protein molecular weight using SDS Polyacrylamide Gel Electrophoresis (SDS-PAGE). Presence of allergenic protein and colloidal stability of the mixture were also evaluated.

\section{High ammoniated latex}

\section{Materials and Methods}

High ammoniated natural rubber latex (HA-NRL) preserved with $0.7 \%$ ammonia was obtained from a local supplier. The dry rubber content (DRC) of HA-NRL was $60 \%$. 


\begin{abstract}
Alcalase
Alcalase was obtained from Novozyme Sdn Bhd. The alcalase solution was diluted to several concentrations in the range of $2 \%$ to $8 \%$ to get the final concentration of $1-4 \%$ when mixed with HA-NRL.
\end{abstract}

\title{
Preparation of high ammoniated natural rubber latex with alcalase
}

The initial concentration of $300 \mathrm{~mL}$ HA-NRL was diluted to $30 \%$ DRC after it was mixed with alcalase in different concentrations from $1 \%$ to $4 \%$. The mixture was stirred continuously for two hours at $100 \mathrm{rpm}$ at ambient temperature.

\section{Measurement of total protein content}

Samples of unleached and leached latex films were prepared by casting the treated HA-NRL on glass plates. For leaching, latex films from each treatment were immersed in water bath at $60{ }^{\circ} \mathrm{C}$ for 5 minutes. Rubber phase from the latex was obtained by centrifugation (Beckman Coulter Optima L-100K Ultracentrifuge) at 30,000 $x \mathrm{~g}$ for 1 hour to separate the rubber from the serum phase. The total protein content in the rubber phase as well as the leached and unleached latex films were determined by measuring their nitrogen contents ( $\mathrm{N} \%$ ) using the Kjedhal method based on AOAC International [16].

\section{Determination of protein molecular weight and detection of allergenic proteins}

The treated latex was firstly centrifuged at $30,000 \times \mathrm{g}$ for $1 \mathrm{hr}\left(\mathrm{T}=5^{\circ} \mathrm{C}\right)$ to obtain a clear serum fraction. The serum fraction was then subjected to SDS - Polyacrylamide Gel Electrophoresis (SDS-PAGE). The SDS-PAGE analysis was conducted at a constant current of $0.25 \mathrm{~A}$ for 1 hour. The reference marker was run concurrently in all experiments. The SDS-PAGE gels were stained with silver staining method followed by destained in destaining solution. Meanwhile, presences of allergenic proteins in the serum and rubber samples were detected by using Latex-T Test Kit.

\section{Zeta potential analysis}

The zeta potential of the alcalase treated HA-NRL was measured using the 90Plus/BI-MAS and ZetaPlus from Brookhaven Instrument Corporation. Sample was diluted to $0.01 \mathrm{wt} \%$ with distilled water and $\mathrm{pH}$ of the sample in a range from 2 to 12 was adjusted with $0.1 \mathrm{M} \mathrm{H}_{2} \mathrm{SO}_{4}$ and $0.1 \mathrm{M} \mathrm{KOH}$ prior to the test.

\section{Statistical analysis}

The data obtained was analyzed by using IBM SPSS Statistic 20, subjected to Compare Means procedure using one way ANOVA.

\section{Results and Discussion \\ Effect of alcalase on protein content of high ammoniated-natural rubber latex}

Leaching process removes water soluble proteins from the latex. Latex is an emulsion that comprises a stable dispersion of rubber particles in an aqueous phase [12]. The aqueous phase is made up of water, non-rubber compounds such as carbohydrates (quebrachitol, sucrose, glucose, fructose and raffinose), proteins and amino acids ( $\alpha$-globulin and hevein), other serum constituents (free nitrogenous bases, lipids, organic acids, inorganic anions and metallic ions) and a range of enzymes [5]. These constituents including proteins that dissolved in the aqueous phase are commonly water soluble and can be removed by washing with water.

Figure 1 shows the effect of leaching on films prepared from HA-NRL treated with varying concentrations of alcalase. The nitrogen content (N\%) of unleached latex film in the absence of alcalase was referred as the initial protein content in the HA-NRL. After two hours incubation time, protein content in the unleached latex films increased proportionally with increasing alcalase concentration. This shows that the total protein content in the treated HA-NRL was influenced by the presence of alcalase. 


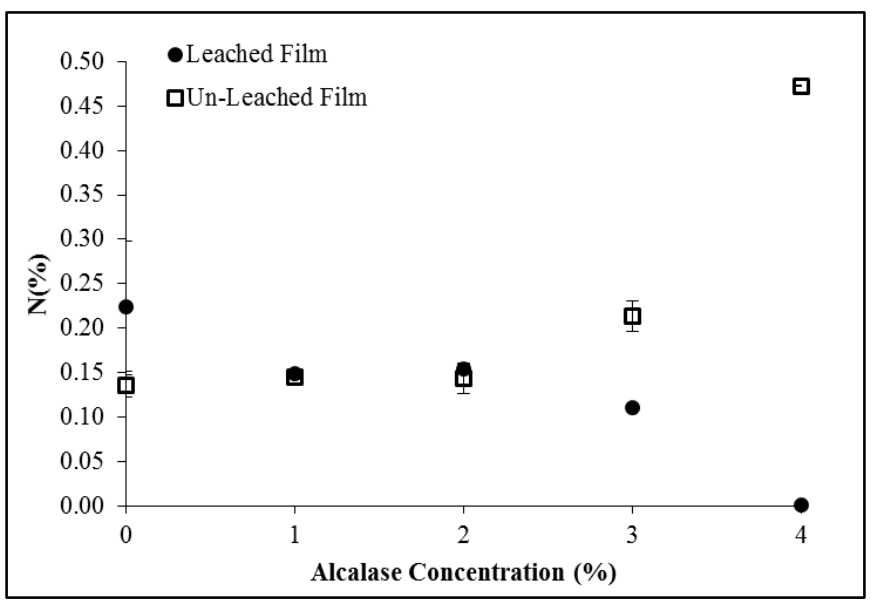

Figure 1. Total nitrogen content of the unleached and leached HA-NRL films in the presence of alcalase

The extent of protein removal from HA-NRL in the presence of alcalase showed two different trends. In the first trend, the amount of $\mathrm{N} \%$ in leached films was not significantly different than the unleached films in the presence of low concentration of alcalase $(1 \%$ and $2 \%)$. Contrary in the second trend, when alcalase concentration was increased to $3 \%$ and $4 \%$, the total amount of proteins in leached HA-NRL film was significantly lower than the unleached film. At this condition, it is possible that most of the accumulated proteins on the latex film surface have been extracted into the leaching water and hence the nitrogen content dropped significantly. Therefore, more water soluble proteins were removed from HA-NRL in the presence of alcalase above $3 \%$ with two hours incubation time.

When the treated HA-NRL was casted on glass plates to make films, drying process of the latex caused water inside the serum to evaporate, along which the non-rubbers components especially proteins, would be drawn to the surface of the latex film eventually. Alcalase is a proteolytic enzyme under the group of serine proteases which belong to subtilases. Subtilisin is a non-specific protease that was initially obtained from certain types of soil bacteria such as Bacillus amyloliquefaciens $[3,16]$. This protein-digestive enzyme attacks the peptide bonds that covalently link the amino acids through a serine residue at the active site of the enzyme. Treating the HA-NRL with alcalase causes proteins digestion or hydrolysis whereby the proteins molecules are cleaved into more smaller sizes. At higher concentration of alcalase, more proteins are truncated by the enzyme. The truncated proteins being of smaller molecular fragments, would be easily moved to the film surface during the drying process. When the films were leached in water subsequently, these proteins would be easily solubilized in water.

The degree of protein hydrolysis by proteolytic enzyme is influenced by the enzyme and substrates concentration [17]. As described by James et al. [18] enzyme concentration generally had a greater effect on accelerating hydrolysis reaction thus able to shorten the reaction time when compared with temperature increment. Generally, the rate of reaction is simultaneuosly increased when more enzyme is added, provided that the substrate concentration is high and kept at constant rate. On the other hand, there is usually a hyperbolic relation between the rate of reaction and the concentration of substrate. The rate of reaction is increased with increasing substrate concentration until a point is reached whereby the active sites of the enzyme molecules are saturated with substrates. As a consequence, any further increment in substrate concentration will not have any affect to the reaction rate.

In this study, the rate of reaction or the degree of protein hydrolysis in the treated HA-NRL could be visualized by looking at the fractionation of proteins in HA-NRL serum based on the difference in molecular weights as shown in Figure 2. Results from SDS-PAGE also confirmed that more proteins were being digested at high concentration of alcalase (4\%). Based on Figure 2, faint bands were observed at the higher molecular weight region, indicating that most of the proteins have been degraded into small molecular weights. As the alcalase concentration increased, there was increased bands at the lower molecular weight region, suggesting that the innate high molecular weight proteins were digested by alcalase into smaller molecular weight protein fragments. 


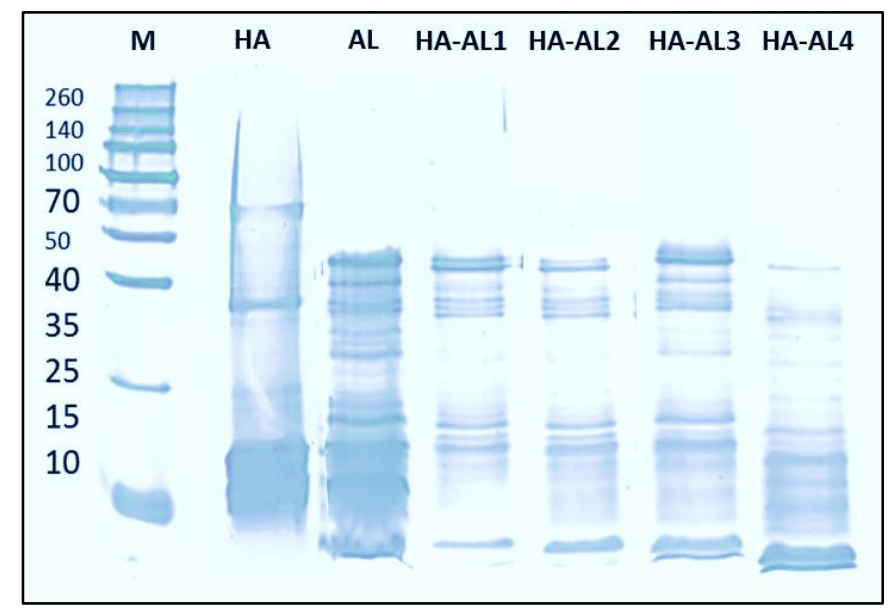

Figure 2. SDS-PAGE of HA-NRL serum after 2-hour incubation with enzymatic treatment; M; protein marker, HA; control (HA-NRL without alcalase), AL; control (alcalase blank), HA-ALx (x-alcalase concentration of $1 \%, 2 \%, 3 \%$ and $4 \%$ )

\section{Effect of alcalase on protein content in white rubber phase of high ammoniated-natural rubber latex}

In this experiment, the HA-NRL was subjected to high speed centrifugation in order to purify the rubber phase from proteins and other non-rubber substances. Presence of nitrogen $(\mathrm{N})$ in the white rubber phase after this process would measure the efficiency of the enzyme in removing the non-rubber substances from the rubber particles surfaces. As discussed earlier in this study, more proteins were digested at higher enzyme concentration. Presumably, after centrifugation process the amount of proteins in the white rubber phase from HA-NRL with high alcalase concentration should as well being reduced. This is due to gravitational forces that would have separated and removed the small protein peptides during centrifugation process.

The relationship between $\mathrm{N} \%$ and alcalase concentration in white rubber phase could be interpreted by dividing the graph into three different parts as shown in Figure 3. In the absence of alcalase, the level of protein content in the white rubber phase of HA-NRL was recorded at $0.07 \%$, which was higher than that of treated HA-NRL. This might be attributed to proteins that were tightly bound to the rubber particles. Interestingly, the protein content in white rubber phase from HA-NRL treated with $1 \%$ of alcalase showed significant reduction of $91 \%$, decreasing from $0.07 \%$ to $0.006 \%$ (Part a). These findings showed that proteins were hydrolysed and cleaved into smaller molecules. The cleaved and lighter molecular weight proteins then entered into the latex serum hence reducing the amount of proteins still locked on to the rubber particle surfaces. The serum proteins were subsequently removed upon centrifugation.

However, as concentration of alcalase was increased (Part b), the amount of proteins in the white rubber phase was proportionally increased up to $3 \%$ of alcalase. This shows that the total protein content in the treated HA-NRL was influenced by the presence of alcalase. Alcalase which is a proteolytic enzyme, digested the native proteins in the latex by cutting the peptide bonds that covalently linked the amino acids, turning the proteins into low molecular weight molecules. Consequently, the proteins could be easily removed by centrifugation or solubilisation with water. However, alcalase itself is a long polypeptide chain of proteins. Therefore, increment of protein content in the white rubber phase of the treated HA-NRL was probably contributed by the peptide chains of alcalase. Meanwhile, in the third part (Part c), no significant changes in protein content was observed. 


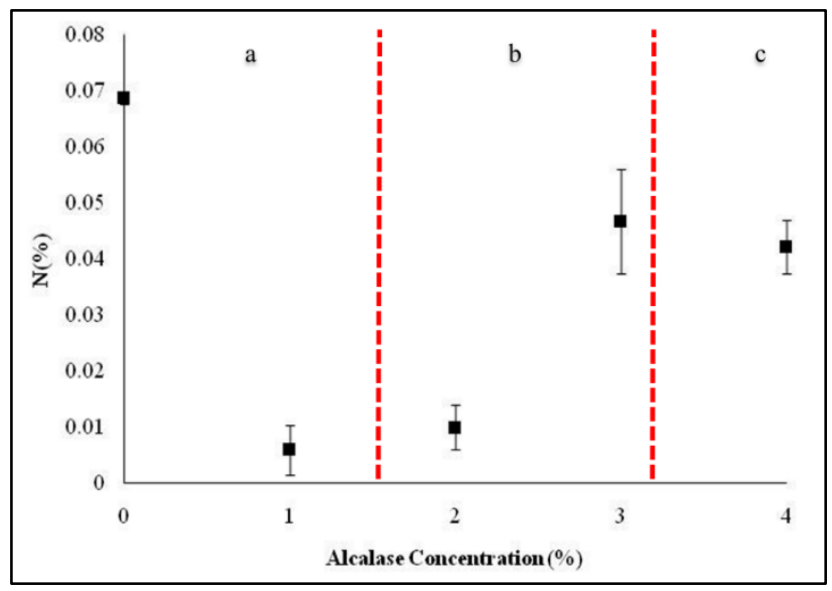

Figure 3. Total nitrogen content from white rubber phase of HA-NRL after centrifugation in different concentration of alcalase

Based on the findings above, there are two hypothetical theories that could likely explain the increase in N\% content in the white rubber phase of HA-NRL in the presence of alcalase after centrifugation process. The first theory is the occurence of adsorption and desorption of protein molecules on the surface of rubber particles. The absorption of other protein peptides on the rubber particles surface could be due to ionic (elecrostatic) bonding or hydrophobic interaction [19]. As described previously by Stoker [20], electrostatic interaction can occur with small peptides and amino acids. Commonly, alcalase consists of a single peptide chain with 274 amino acid residues in the absence of disulfide bonds [21]. A study by Tangboriboonrat et al. [22] implied that certain proteins and other non-rubber substances still have the possibilities to remain intact on the rubber particle surfaces after deprotenization process. The small peptides resulted from hydrolysed proteins in HA-NRL that might still be bound on the rubber particles surface could electrostatically interact with amino acids derived from the alcalase. Subsequently, amide bond between amine and carboxylic acid functional groups in the small peptide and the amino acids would be formed and resulted in new chains of amino acids. An empty space left by the digested protein might be replaced by the free floating protein peptides of alcalase. The weakly modified rubber particle surface due to reduction in negatively charged protein provides a hydrophobic surface that other protein molecules could adsorb to. Concentration gradient is one of the factors that influences the transport of proteins to a solid surface [23]. Therefore, the tendancy of nonpolar hydrophobic region in alcalase to interact with the rubber particles surface will eventually increase when the concentration of alcalase is increased.

Meanwhile in the second theory, increment or reduction of proteins in the white rubber phase might be influenced by the rate of hydrolysis and aminolysis reaction. In the presence of large amount of substrates and limited amount of water, there is a tendency of the proteolytic enzyme to act in the opposite direction, leading to the formation of new peptides bonds also known as aminolysis [24]. As enzyme concentration increases, competition between hydrolysis and aminolysis reaction might occur. Thus, under this circumstance the carboxy terminal modified amino acid ethyl ester of the protein from the substrate will act as nucleophile and binds to the active site of the proteolytic enzyme to initiate chain length propagation [25]. This reaction could happen on rubber particles surface as shown in Figure 4. As a result, the total nitrogen content on the rubber particles increased as indicated by the total nitrogen content in the white rubber phase of treated HA-NRL.

Study by Tangpakdee and Tanaka [26] found that insignificant change in the molecular weight of rubber was observed which showed proteolytic enzyme broke down proteins selectively at certain sites of the amino acids chain and remained as oligopeptide groups that form branched molecules. Furthermore, enzymatic treatment in latex could not remove the free fatty acid components although there was reduction in the amount of phosphorus after the treatment. The remaining free fatty acid components after proteolysis reaction were believed to be derived from phospholipids, a main component that could also form branched molecules [27]. 


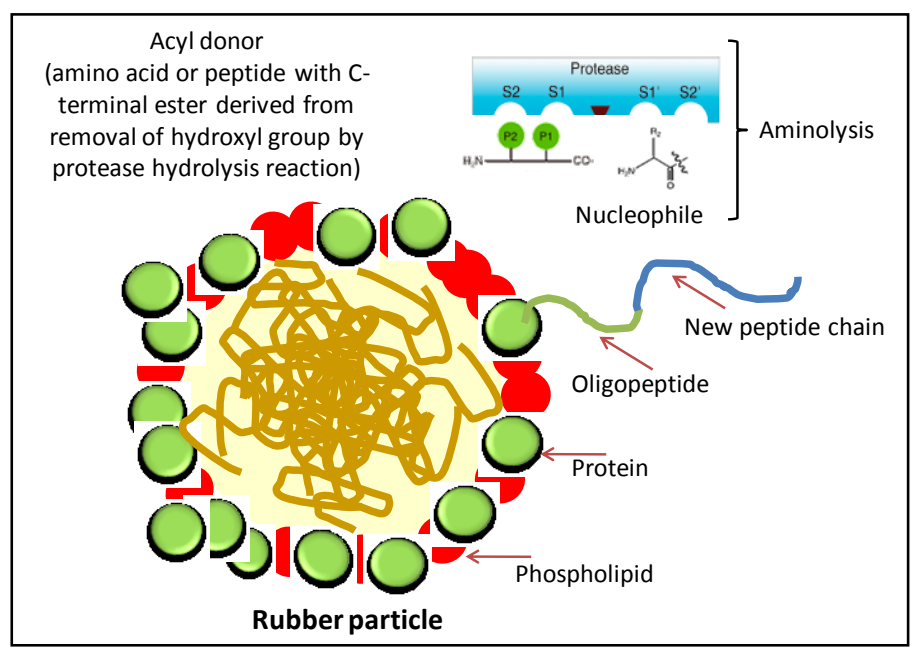

Figure 4. Schematic representation of hypothesize aminolysis reaction on the rubber particle surfaces

\section{Effect of alcalase on allergenic protein in high ammoniated-natural rubber latex}

The Latex-T Diagnostic Kit detected the presence of two major types of allergenic proteins that represented as Blue allergen and Red allergen. In the absence of alcalase the concentration of Red allergen was significantly higher than Blue allergen (Figure 5). Interestingly, the concentration of Red allergen in HA-NRL treated with 1\% of alcalase was significantly reduced and continue to drop until at $4 \%$ alcalase concentration. In the contrary, insignificant changes of Blue allergen in the treated HA-NRL was observed. The results indicated that the proteolytic enzyme is effectively reduce the amount of Red allergen compared to Blue allergen. Therefore, the proteolytic enzyme has the potential to act as deproteinizing agent that could assist in reducing the allergenic risk from NRL.

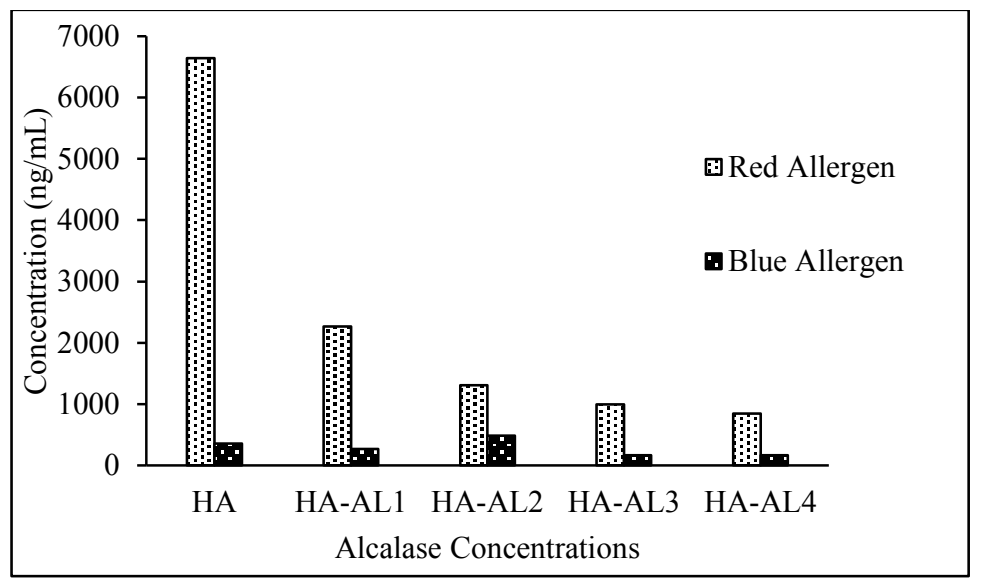

Figure 5. Concentration of major allergenic proteins in HA-NRL in different concentration of alcalase

\section{Effect of alcalase on the colloidal stability of high ammoniated-natural rubber latex}

According to Salopek et al. [28] zeta potential or also known as electrokinetic is used to observe the behaviour of dispersive systems in liquids. The potential stability of a colloidal system can be represented by the magnitude of the zeta potential. Whenever a particle is disperses in a liquid medium, it will forms an interfacial region on the particle surface. The interfacial region consists of ions of opposite charge to that of particle that closely located to the particle surface (Stern layer), and counter ions that loosely associated with the particle (diffuse layer). These 
layers are referred as the electrical double layer. The potential magnitude of zeta potential is measured at the boundary of the diffuse layer that adjacent to the bulk dispersant or known as surface of hydrodynamic shear [29].

The potential stability of the colloidal systems as indicated by the zeta potential is depending on the concentration of ions. High concentration of ions with positive or negative charges will resulted in stable colloidal systems in which coagulation between the particles will be absence. Charges on the particles also contribute to the electrostatic repulsion that caused the particles to repel from each other. Absence of any positive or negative ion charges will reduce the electrostatic repulsion and thus there will be no force to prevent the particles coming together and agglomerate. Changes on the concentration of ions on the particles surface that influence the stability of a suspension can be observed from a graph plotted with zeta potential $(\mathrm{mV})$ versus $\mathrm{pH}$. In aqueous media, the $\mathrm{pH}$ of the sample is one of the most important factors that affect zeta potential of the particles [30]. Balance between the positive and negative charges presence in a suspension is influence by the $\mathrm{pH}$. At a specific $\mathrm{pH}$ the positive and negative charges will be equal and the net charge will be zero. The $\mathrm{pH}$ where a colloidal system reaches its neutralization state is called the isoelectric point (IEP). At this point the suspension is at the least stable condition due to absence of inter-particle repulsive forces. As a rule of thumb, stability of the particles in a colloidal system is generally taken at either above +30 or $-30 \mathrm{mV}[31]$.

Figure 6 shows the zeta potential analysis for treated HA-NRL samples recorded over $\mathrm{pH}$ range from $\mathrm{pH} 2$ to $\mathrm{pH}$ 10. Based on the graph, the IEP for all samples were below than pH4. HA-NRL consists of latex particles with more negative charges as shown by the IEP value. As $\mathrm{pH}$ decreases, abundant presence of $\mathrm{H}^{+}$ions caused the latex particles to lose their negative charges until they reach the neutralization state at $\mathrm{pH} 2$ and eventually became more stable as the $\mathrm{pH}$ increased (above $\mathrm{pH}$ 4). However, the HA-NRL treated samples showed a different trend in which more $\mathrm{OH}^{-}$were needed in order to reach the IE point as shown by the increasing in $\mathrm{pH}$ (above $\mathrm{pH} 2$ ). Thus indicate that the latex particles in the treated HA-NRL were having less negative ions concentration when compared with HA-NRL in the absence of alcalase. This result could be implied with previous finding by Salgin et al. [32] mentioned that, the difference in the IEP can be due to different in ionic environment such as ionic strength, $\mathrm{pH}$ and ion type. Different in ions concentration could possibly influence by the presence of alcalase that also carried charges proteins. The isoelectric point for alcalase is 9.4 which is near to 12. Protein with isoelectric point of 12 or more, are most likely having side chains of amino acid that positively charges [33].

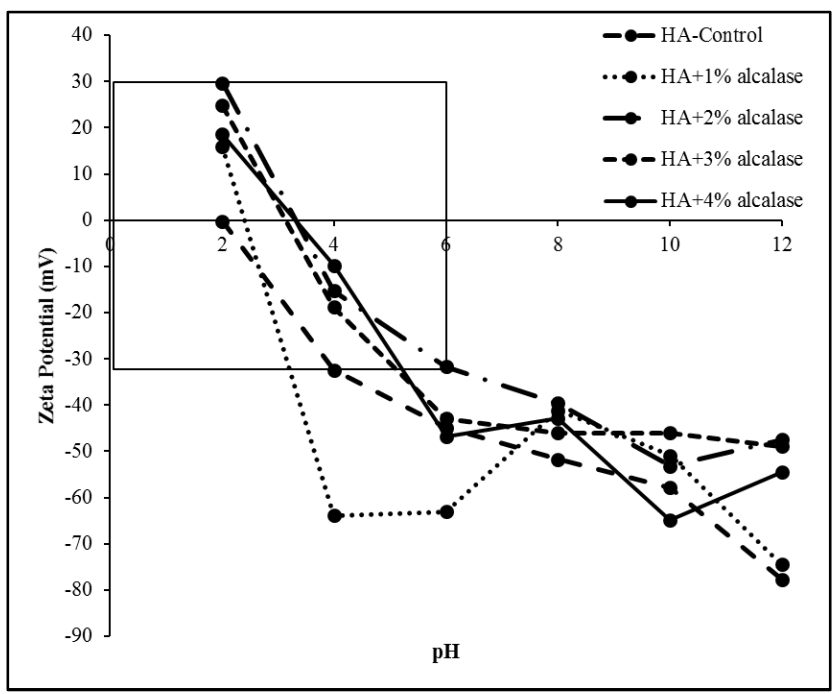

Figure 6. Zeta potential behaviour in a function of $\mathrm{pH}$ 


\section{Conclusion}

Enzymatic treatment of HA-NRL effectively hydrolysed the protein molecules in the serum and increased the amount of water-soluble proteins in which could be removed easily by water leaching process. Hydrolysis reaction in the serum increased steadily proportional to the increment in proteolytic enzyme concentration. This finding was also supported by the results from SDS-PAGE analysis which showed most of the protein bands were located at the low molecular weight region in the presence of $4 \%$ alcalase concentration. Nevertheless, instead of reducing the protein content in the white rubber phase of HA-NRL, different proteolytic enzyme concentrations triggered different reactions. The ratio of enzyme and substrate (i.e. latex in this study) concentration significantly influenced the proteolytic enzyme activity. It was found that at $1 \%$ of alcalase concentration, drastic reduction of $\mathrm{N} \%$ in white rubber phase was observed. Further investigation is needed on the effect of proteolytic enzyme on mechanical and colloidal stability of treated HA-NRL. Nevertheless, results from this study indicates that low concentration of alcalase is sufficient to reduce the protein content with the possibility to produce HA-NRL that has low allergenicity risk.

\section{Acknowledgements}

The authors wish to thank the Director General of the Malaysian Rubber Board for the permission to publish this paper and the support given for technical and financial assistances for the project. We appreciate the advices and comments made by the Panel of the Scientific Economic and Advisory Committee (SEAC) during the proposal and monitoring stage of the study. Not to be forgotten are the capable technical work and support rendered by Mr. Hanipiah Basri.

\section{References}

1. Kroschwitz, J. (1990). Concise encyclopedia of polymer science and engineering. Wiley InterScience of John Wiley \& Sons, Inc., Hoboken, pp. 24-64.

2. Blomfield, G. F. (1951). The rubber hydrocarbon in freshly tapped Hevea latex. Rubber Chemistry and Technology. 24(4): 737-749.

3. Blackley, D. C. (1997). Types of latices. Polymer latices: Science and technology Volume 2: Springer Science and Business Media.

4. Angrove, S. N. (1964). Preservation of NR latex concentrate; Part I-method of evaluation and evaluation of existing preservative systems. Transactions of the Institution of the Rubber Industry: 40.

5. Hasma, H. and Subramaniam, A. (1986). Composition of lipids in latex of Hevea brasiliensis clone RRIM 501 [Malaysia]. Journal of Natural Rubber Research, 1: 30-40.

6. Tata, S. J. (1980). Distribution of proteins between the fractions of Hevea latex separated by ultracentrifugation. Journal of Rubber Research Institute of Malaysia, 28: 77-85.

7. Archer, B. L., Barnard, E.G., Cockbain, J.W., Cornforth, R.H. and Popjak, G. (1966). The stereochemistry of rubber biosynthesis. Proceedings of the Royal Society B: Biological Sciences, 163: 519-523.

8. Yeang, H. Y., Arif, S. A. M., Yusof, F. and Sunderasan, E. (2002). Allergenic proteins of natural rubber latex. Methods, 27: 32-45.

9. Sussman, G. L., Beezhold, D. H. and Kurup, V. P. (2002). Allergens and natural rubber proteins. Journal of Allergy and Clinical Immunology, 110: S33-S39.

10. Aprem A. B. and Satyendra N. P. (2002). Latex allergy and recent developments in deproteinisation of natural rubber latex. Journal of Rubber Research Institute of Malaysia, 5: 94-134

11. Perrella, F. W. and Gaspari, A. A. (2002). Natural rubber latex protein reduction with an emphasis on enzyme treatment. Methods, 27: 77-86.

12. Manroshan, S., Asrul Mustafa, Mok, K. L., Kawahara, S., Amir-Hashim M. Y. and Booten, K. (2009). Comparison between sodium dodecyl sulfate and polyfructose surfactant systems in urea deproteinisation of natural rubber latex. Journal of Rubber Research Institute of Malaysia, 12: 1-11.

13. Gazeley, K. F., Gorton, A. D. T. and Pendle, T. D. (1988). Natural rubber science and technology in ed. by A. D. Roberts (England: Oxford University Press): 63-98.

14. Yatim, A. H. M. (1997). Effect of natural latex non-rubbers on the vulcanisation and physical behaviour of natural rubber latex films. PhD Dissertation. University of North London, England.

15. AOAC (2000). Official methods of analysis. AOAC International. 
16. Priest, F. G., Goodfellow, M., Shute, L. A. and Berkeley, R. C. W. (1987). Bacillus amyloliquefaciens sp. nov., nom. rev. International Journal of Systematic Bacteriology, 37: 69-71.

17. Salwanee, S., Wan Aida, W. M., Mamot, S., Askat, M. Y. M. and Im, S. I. (2013). Effects of enzyme concentration, temperature, $\mathrm{pH}$ and time on the degree of hydrolysis of protein extract from viscera of tuna (Euthynnus affinis) by using alcalase. Sains Malaysiana, 42: 279-287.

18. James, I. T., Philip, B. G. and Sheila, A. B. (2005). Optimization of conditions for the enzymatic hydrolysis of phytoestrogen conjugates in urine and plasma. Analytical Biochemistry, 341(2): 220-229

19. Kim, J. (2002). Protein adsorption on polymer particles. Journal of Biomedical Materials Research, 21: 43734381.

20. Stoker, H. S. (2015). General, Organic, and Biological Chemistry. Cengage Learning.

21. Cowan, D., Daniel, R. and Morgan, H. (1985). Thermophilic proteases: Properties and potential applications. Trends in Biotechnology, 3: 68-72.

22. Tangboriboonrat, P., Tiyapiboonchaiya, C. and Lerthititrakul, C. (1998). New evidence of the surface morphology of deproteinized natural rubber particles. Polymer Bulletin, 41: 601-608.

23. Dee, K. C., Puleo, D. A. and Bizios, R. (2003). An introduction to tissue-biomaterial interactions. John Wiley $\&$ Sons.

24. Yazawa, K. and Numata, K. (2014). Recent advances in chemoenzymatic peptide syntheses. Molecules, 19: 13755-74.

25. Baker, P. J., Patwardhan, S. V and Numata, K. (2014). Synthesis of homopolypeptides by aminolysis mediated by proteases encapsulated in silica nanospheres. Macromolecular Bioscience, 14: 1619-1626.

26. Tangpakdee, J. and Tanaka, Y. (1997). Characterization of sol and gel in hevea natural rubber. Rubber Chemistry and Technology, 70: 707-713.

27. Sakdapipanich, J. T. (2007). Structural characterization of natural rubber based on recent evidence from selective enzymatic treatments. Journal of Bioscience and Bioengineering, 103: 287-292.

28. Salopek, B., Krasic, D. and Filipovic, S. (1992). Measurement and application of zeta-potential. Rudarskogeoloiko-naftni zbornik, 4: 147-151.

29. Kaszuba, M., Corbett, J., Watson, F. M.and Jones, A. (2010). High-concentration zeta potential measurements using light-scattering techniques. Philosophical Transactions of The Royal Society A Mathematical Physical and Engineering Sciences, 368: 4439-4451.

30. Prabhu, S. and Murugan, K. (2015). Zeta potential measurements in colloidal suspensions. International Conference on Systems, Science, Control, Communication, Engineering and Technology: pp. 221-224.

31. Honary, S. and Zahir, F. (2013). Effect of zeta potential on the properties of nano-drug delivery systems -A review (Part 2). Tropical Journal of Pharmaceutical Research, 12(2): 265-265.

32. Salgın, S., Salgın, U. and Bahadır, S. (2012). Zeta potentials and isoelectric points of biomolecules: the effects of ion types and ionic strengths. International Journal of Electrochemical Science, 7: 12404-12414.

33. Gençkal, H. (2004). Studies on alkaline protease production from Bacillus sp. Master Dissertation. Izmir Institute of Technology, Turkey. 